Article

\title{
Potential Use of Plant Waste from the Moth Orchid (Phalaenopsis Sogo Yukidian "V3") as an Antioxidant Source
}

\author{
Truong Ngoc Minh ${ }^{1}$ (D), Phung Thi Tuyen ${ }^{1}$, Do Tan Khang ${ }^{1}$ (D), Nguyen Van Quan ${ }^{1}$, \\ Pham Thi Thu Ha ${ }^{1}$, Nguyen Thanh Quan ${ }^{1}$, Yusuf Andriana ${ }^{1}{ }^{10}$, Xinyan Fan ${ }^{1}$, Truong Mai Van ${ }^{1}$, \\ Tran Dang Khanh ${ }^{2}$ and Tran Dang Xuan ${ }^{1, *}$ \\ 1 Graduate School for International Development and Cooperation, Hiroshima University, \\ Hiroshima 739-8529, Japan; minhtn689@gmail.com (T.N.M.); phungtuyen@gmail.com (P.T.T.); \\ dtkhang@ctu.edu.vn (D.T.K.); nguyenquan26@gmail.com (N.V.Q.); phamthithuhabt@gmail.com (P.T.T.H.); \\ quanagi@gmail.com (N.T.Q.); yusufandriana@yahoo.com (Y.A.); xinyanfan5160@gmail.com (X.F.); \\ truongmaivan1991@gmail.com (T.M.V.) \\ 2 Division of Genetic Engineering, Agricultural Genetics Institute, Pham Van Dong Street, Hanoi 10000, \\ Vietnam; khanhkonkuk@gmail.com \\ * Correspondence: tdxuan@hiroshima-u.ac.jp; Tel./Fax: +81-82-424-6927
}

Received: 16 July 2017; Accepted: 23 September 2017; Published: 27 September 2017

\begin{abstract}
This research was conducted to exploit the waste of used plant parts from the widely marketed moth orchid cultivar (Phalaenopsis Sogo Yukidian "V3"). Various extracts of roots, stems, and leaves were evaluated for total phenolics, total flavonoids, and antioxidant capacity. The bound extract from stems contained the highest total phenolics (5.092 $\pm 0.739 \mathrm{mg}$ GAE (gallic acid equivalent) $/ \mathrm{g}$ DW (dry weight)). The maximum total flavonoids $(2.218 \pm 0.021 \mathrm{mg} R E$ (rutin equivalent)/g DW) were found in the hexane extract of leaves. Ethyl acetate extract from roots showed the greatest antioxidant activity compared to other extracts. Of these extracts, the $\mathrm{IC}_{50}$ values of these samples were $0.070 \mathrm{mg} / \mathrm{mL}$, and $0.450 \mathrm{mg} / \mathrm{mL}$ in a free radical 1,-diphenyl-picryl-hydrazyl (DPPH) assay and reducing power method, respectively. The lipid peroxidation inhibition (LPI) was found to be $94.2 \%$ using the $\beta$-carotene bleaching method. Five phenolic compounds including caffeic acid, syringic acid, vanillin, ellagic acid, and cinnamic acid were quantified by high performance liquid chromatography (HPLC). It is suggested that the roots of the hybrid Phalaenopsis Sogo Yukidian "V3" cultivar may be exploited as an effective source of antioxidants.
\end{abstract}

Keywords: Phalaenopsis Sogo Yukidian "V3"; antioxidant activity; moth orchids; phenolic acids; plant part waste

\section{Introduction}

Phytoplankton is a rich source of phytochemicals and antioxidants. A considerable number of studies have been conducted regarding new forms of antioxidants due to their known health benefits [1]. Natural antioxidants are an important source for preventing or scavenging free radicals and reducing chronic and degenerative diseases by slowing the aging process and treating cancer. Secondary metabolites, of which phenolic compounds are a key component, have diverse applications in antioxidant production. Thus, recent replacement of synthetic antioxidants with natural compounds and the identification of new antioxidants have become very important [2].

The genus Phalaenopsis (moth orchids) comprises about 66 species belonging to the Orchidaceae family (estimated $>25,000$ species) [3,4]. Among them, the Phalaenopsis (Phal.) Sogo Yukidian "V3" cultivar (moth orchid), which is a hybrid of Phal. Yukimai crossed with Phal. Taisuco Kochdian 
varieties, is white-colored, has a large flower, and is common in the market [4]. The Phal. crinkled flowers indicates relatively short flower longevity, with young seedlings typically propagated by tissue culture [5]. This cultivar of orchid is also a popular potted plant in Japan, America, and Europe [6]. The plant becomes very weak after flowering one or two times, subsequently turning into waste [2]. Moreover, although this orchid has great economic value, its disposal has proven to bring about detrimental effects on the environment $[2,7,8]$. Therefore, the objective of this study was to evaluate the antioxidant properties of plant part waste of the moth orchid.

Phenolic compounds exist in both free and bound forms in plant cells. Free phenolic compounds are extractable with solvents, while bound phenolic compounds are covalently bound to the plant matrix [9]. Therefore, different extraction techniques using increasingly polar solvents, including hexane, chloroform, ethyl acetate, and water, were applied to examine their efficacy for extracting antioxidants and evaluate the antioxidant capacity, total phenolics, and total flavonoids in the orchid. The identification and quantification of individual phenolic acids were also conducted.

\section{Materials and Methods}

\subsection{Materials}

The hybrid Phal. Sogo Yukidian "V3" cultivar used in this study was grown in a greenhouse at the Kurousu Orchid Company, Saitama Prefecture, Japan from April 2014 to July 2015. After flowering, the whole plant was collected and used for the experiment. Leaves, roots, and stems of this hybrid orchid were cut separately into small pieces and dried in an oven at $30^{\circ} \mathrm{C}$. After drying, the samples were ground into powder using a kitchen grinder.

\subsection{Preparation of Free Phenolics and Bound Phenolics}

Different extracting solvents with increasing polarity were used to examine the efficacy of different extracts on orchid plant parts. The solvents used included the following compounds: hexane, chloroform, ethyl acetate, and water (Table 1). Dried plant part powder was first separated into groups of stems, roots, and leaves. Next, these groups were placed in ethanol and were concentrated under reduced pressure at $40^{\circ} \mathrm{C}$. The resulting dried ethanol extracts were then dissolved in water and successively extracted with each of the solvent compounds, hexane, chloroform, and ethyl acetate. The resulting mixtures were added to the aqueous solution that remained following extraction. These mixtures were filtered and concentrated under decreased pressure to obtain extracts in hexane, chloroform, ethyl acetate, and aqueous extracts [10]. The ethanol residues were hydrolyzed with $4 \mathrm{M}$ $\mathrm{NaOH}$ at $50{ }^{\circ} \mathrm{C}$ and extracted with ethyl acetate to obtain bound phenolics [11].

Table 1. Names and abbreviations of plant extracts with different solvents.

\begin{tabular}{ll}
\hline Name of Plant and Extraction Solvent & Abbreviation \\
\hline Sogo Yukidian "V3" stem free hexane & SFH \\
Sogo Yukidian "V3" stem free chloroform & SFC \\
Sogo Yukidian "V3" stem free ethyl acetate & SFEA \\
Sogo Yukidian "V3" stem free aqueous & SFA \\
Sogo Yukidian "V3" root free hexane & RFH \\
Sogo Yukidian "V3" root free chloroform & RFC \\
Sogo Yukidian "V3" root free ethyl acetate & RFEA \\
Sogo Yukidian "V3" root free aqueous & RFA \\
Sogo Yukidian "V3" leaf free hexane & LFH \\
Sogo Yukidian "V3" leaf free chloroform & LFC \\
Sogo Yukidian "V3" leaf free ethyl acetate & LFEA \\
Sogo Yukidian "V3" leaf free aqueous & LFA \\
Sogo Yukidian "V3" stem bound & SB \\
Sogo Yukidian "V3" root bound & RB \\
Sogo Yukidian "V3" leaf bound & LB \\
\hline
\end{tabular}




\subsection{Total Phenolic Content}

The Folin-Ciocalteu method was used to determine the phenolic content of both free phenolics or bound phenolics of plant extracts, of which, the total phenolic content was calculated using a calibration curve and presented as mg of gallic acid equivalent (GAE)/g dry weight (DW) [12].

\subsection{Estimation of Flavonoid Content}

The aluminum chloride colorimetric assay was used to determine the flavonoid content of both free phenolics and bound phenolics of plant extracts, of which, the total flavonoid content was established using a calibration curve and expressed as mg rutin equivalent/g DW [13].

\subsection{Antioxidant Activity Measurement by DPPH Scavenging Assay}

Experiments were carried out according to the method described in Elzaawely et al. [14]. The reaction mixture of $0.5 \mathrm{~mL}$ of sample extract, BHT (butylated hydroxytoluene) (positive control), or $\mathrm{MeOH}$ (methanol) (control), $0.25 \mathrm{~mL}$ of $0.5 \mathrm{mM} \mathrm{DPPH}$, and $0.5 \mathrm{~mL}$ of $0.1 \mathrm{M}$ acetate buffer (pH 5.5), were kept in the dark at $26^{\circ} \mathrm{C}$ for $30 \mathrm{~min}$. A HACH DR/4000U spectrophotometer (Hach, Loveland, CO, USA) was used to evaluate the absorbance at $517 \mathrm{~nm}$. The rate of inhibition percentage was determined according to the formula: \% radical scavenging activity $=\left[\left(\mathrm{A}_{\text {control }}-\mathrm{A}_{\text {test }}\right) / \mathrm{A}_{\text {control }}\right] \times 100$. The inhibitory concentration $\left(\mathrm{IC}_{50}\right)$ of the sample extracts is the amount needed to inhibit $50 \%$ of the $\mathrm{DPPH}$ radicals. As such, lower $\mathrm{IC}_{50}$ values show higher antioxidant activity.

\subsection{Antioxidant Activity Measurement by $\beta$-Carotene Bleaching Method}

Experiments were carried out according to the method described by Siddhuraju and Becker [15]. A one $\mathrm{mL}$ solution of $\beta$-carotene $(2.0 \mathrm{mg})$ in $10 \mathrm{~mL}$ chloroform, $20 \mu \mathrm{L}$ linoleic acid, and $200 \mathrm{mg}$ Tween-40 was mixed. An aliquot of $50 \mathrm{~mL}$ of oxygenated water was added after concentration under reduced pressure at $45^{\circ} \mathrm{C}$. After shaking, $1 \mathrm{~mL}$ the $\beta$-carotene linoleic acid emulsion was mixed with $120 \mathrm{~mL}$ (1000 ppm) of sample extracts, BHT (positive control), or $\mathrm{MeOH}$ (control). The samples were then incubated at $50{ }^{\circ} \mathrm{C}$. The absorbance of each mixture was measured by spectrophotometer at $492 \mathrm{~nm}$, at an interval of 15-180 min to quantify the absorbance for all samples. Lipid peroxidation inhibition (LPI) percentage was calculated using the following formula [16]: \% $\mathrm{LPI}=\mathrm{A}_{1} / \mathrm{A}_{0} \times 100$.

$A_{0}$ corresponds to the absorbance value estimated at time zero for the test sample, and $A_{1}$ corresponds to the absorbance value at $180 \mathrm{~min}$.

\subsection{Reducing Power}

The reducing power was determined following previously described methods [17]. A reaction mixture of $1 \mathrm{~mL}$ of either extract or BHT (with concentrations 25, 50, 100, and $250 \mathrm{ppm}$ in $\mathrm{MeOH}$ ) and $2.5 \mathrm{~mL}$ phosphate buffer $(0.2 \mathrm{M}, \mathrm{pH} 6.6)$ and $2.5 \mathrm{~mL}$ potassium ferricyanide $\left[\mathrm{K}_{3} \mathrm{Fe}(\mathrm{CN})_{6}\right](10 \mathrm{~g} / \mathrm{L})$ was prepared. Next, the solution was incubated at $50{ }^{\circ} \mathrm{C}$ for $30 \mathrm{~min}$. Following incubation, a total of $2.5 \mathrm{~mL}$ trichloroacetic acid $(100 \mathrm{~g} / \mathrm{L})$ was added to the mixture, which was then centrifuged at $4000 \mathrm{rpm}$ for $10 \mathrm{~min}$. Finally, the supernatant solution $(0.5 \mathrm{~mL})$, distilled water $(0.5 \mathrm{~mL})$, and $0.5 \mathrm{~mL}$ $\mathrm{FeCl}_{3}(1 \mathrm{~g} / \mathrm{L})$ was measured for absorbance at $700 \mathrm{~nm}$. The absorbance of the reaction mixture is directly proportional to reducing power.

\subsection{HPLC Analysis}

Phenolic compound analyses were carried out using HPLC by a method described in Xuan et al. [18]. Five $\mathrm{mL}$ of each sample extract was first filtered using a $0.2 \mu \mathrm{m}$ filter (KANTO Chemical, Tokyo, Japan) and then injected into the HPLC (JASCO PU-2089 Plus, JASCO Corporation, Tokyo, Japan, column J-Pak Symphonia C18 column; $225 \mathrm{~mm} \times 4.6 \mathrm{~mm}$., i.d., $5 \mu \mathrm{m}, 100 \AA(\AA$ is an unit of length equal to $1 \times 10-10$ meters $(\mathrm{m})$ or 0.1 nanometer $(\mathrm{nm}))$. A gradient elution of two solvents including absolute methanol (A) and $0.1 \%$ acetic acid (B) was used. The initial step began with the 
mobile phase A with gradient concentration from $5 \%$ to $10 \%$ in the first $5 \mathrm{~min}$, then increased from $10 \%$ to $90 \%$ for next $45 \mathrm{~min}$, and $100 \%$ for the last $10 \mathrm{~min}$; wavelength: $254 \mathrm{~nm}$; flow rate: $1.0 \mathrm{~mL} / \mathrm{min}$. Each sample was measured in triplicate, and each phenolic compound was identified and quantified in comparison with retention times and peak areas of their respective standards.

\subsection{Statistical Analysis}

All data from this research were analyzed using Minitab Software (version 16.0, copyright 2015, Minitab Inc., State College, PA, USA) which performed a two-way analysis of variance (ANOVA) with $p<0.05$. All trials were conducted using a completely randomized block design with at least three replicates.

\section{Results}

\subsection{Total Phenolic Content (TPC) and Total Flavonoid Content (TFC)}

Different chemicals have various protective and therapeutic effects and may help in the prevention of illness and in maintaining good health [19]. Among them, flavonoids and phenolics are highly effective antioxidants. Some diseases have been treated through the application of polyphenols and flavonoids associated with free radical based terminators, and they have been reported to be effective in disease control as well as involvement in many physiological functions $[20,21]$. Phenolic compounds have been highlighted as antioxidants, which act as free radical oxidant binders, having been shown to elicit pharmacological activity and express biological properties [22,23]. Das et al. [24] mentioned that some flavonoids containing hydroxyls contribute to the narrowing effect of the roots of many plants. The flavonoid mechanism of action is accomplished through either scavenging or chelating. It is well known that many plants are highly effective in the collection of free radicals and antioxidants. Thus, plant phenolics are generally highly effective in removing free radicals [25]. The contents of total phenolics and flavonoids in hexane, chloroform, ethyl acetate, and aqueous extracts prepared from the whole plant of the Phal. Sogo Yukidian "V3" cultivar vary between 0.66 and $9.10 \mathrm{mg}$ GAE/g DW and 0.21 to $3.00 \mathrm{mg}$ rutin equivalent (RE)/g DW, as shown in Figure 1. These results suggest that the highest amount of phenolics was detected in bound extract in comparison with flavonoids and were observed principally in the hexane extracts.

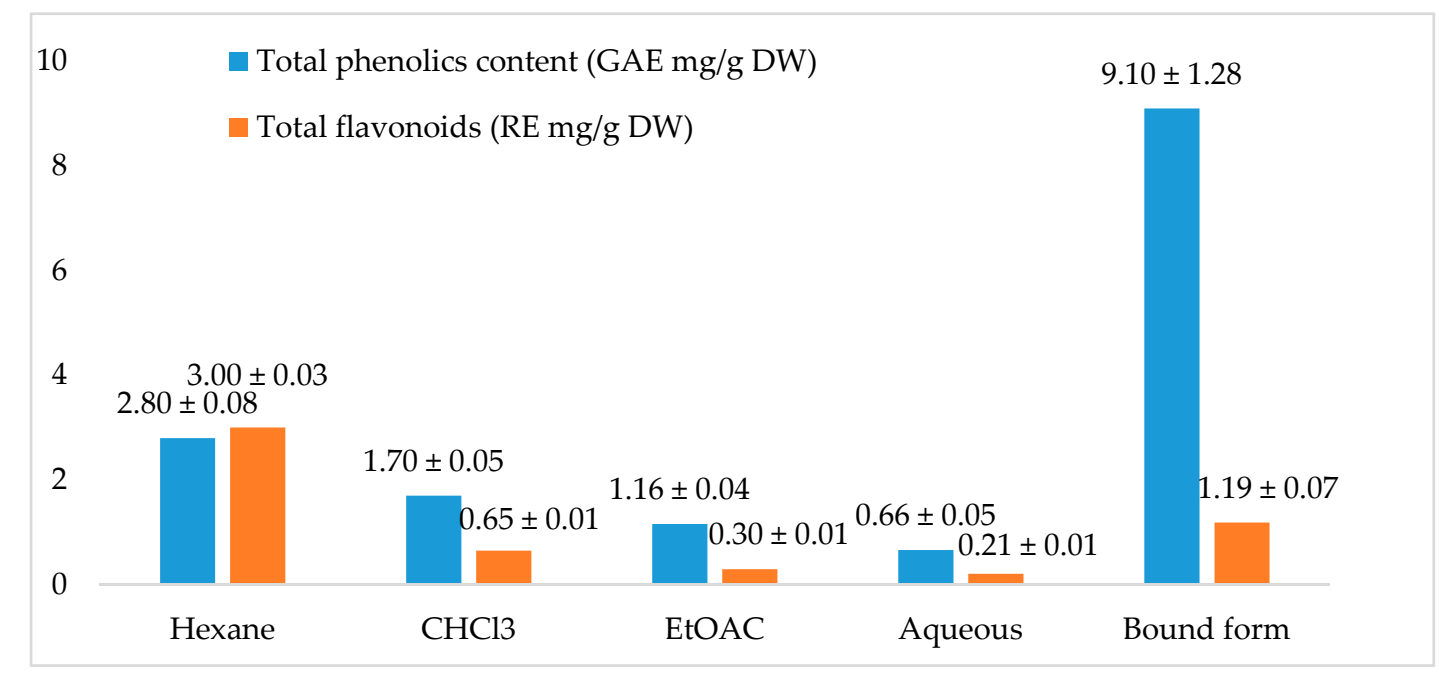

Figure 1. Total phenolic and flavonoid content in extracts of plant parts of Phal. Sogo Yukidian "V3" cultivar. Values represent each mean \pm standard deviation (SD) $(p<0.05)(n=3)$; GAE: gallic acid equivalent; RE: rutin equivalent; DW: dry weight. 


\subsection{Antioxidant Activity by the DPPH Radical Scavenging Assay}

At room temperature, a stable, free radical DPPH creates a violet solution in ethanol, while an antioxidant shows a colorless solution in aqueous ethanol [2]. DPPH is an easy and accurate way to determine antioxidant presence in plant specimens [14]. DPPH reagents provide a convenient and accurate method for titrating a collective oxidation of natural or synthetic antioxidants [26]. The DPPH free radical scavenging activity of the orchid extracts is shown in Table 2, and is exhibited through the $\mathrm{IC}_{50}$ value, of which a smaller value indicates greater activity [27]. Consequently, the $\mathrm{IC}_{50}$ values of free phenolic extracts prepared from an aqueous extract of stems and leaves were higher than $3 \mathrm{mg} / \mathrm{mL}$, indicating a lower antioxidant activity. Contrarily, the corresponding $\mathrm{IC}_{50}$ values of the ethyl acetate extracts were in lower antioxidant levels, ranging from $0.070 \mathrm{mg} / \mathrm{mL}$ in the root samples to $0.699 \mathrm{mg} / \mathrm{mL}$ in the leaf samples. The ethyl acetate root extract only required $0.07 \mathrm{mg} / \mathrm{mL}$ to reduce the DPPH radicals by $50 \%$. On the other hand, the $\mathrm{IC}_{50}$ of the chloroform and hexane extracts in each plant part varied from 0.175 to $1.737 \mathrm{mg} / \mathrm{mL}$.

Table 2. DPPH radical scavenging activity of Phal. Sogo Yukidian "V3" cultivar extracts in terms of $\mathrm{IC}_{50}$ values.

\begin{tabular}{cccc}
\hline \multirow{2}{*}{ Samples } & \multicolumn{3}{c}{ DPPH IC $_{\mathbf{5 0}}(\mathbf{m g} / \mathbf{m L})$} \\
\cline { 2 - 4 } & Stems & Roots & Leaves \\
\hline Hexane & $1.634 \pm 0.020^{\mathrm{b}}$ & $1.663 \pm 0.083^{\mathrm{a}}$ & $\mathrm{ns}$ \\
Chloroform & $0.175 \pm 0.002^{\mathrm{d}}$ & $0.210 \pm 0.005^{\mathrm{d}}$ & $1.737 \pm 0.040^{\mathrm{b}}$ \\
Ethyl Acetate & $0.195 \pm 0.001^{\mathrm{d}}$ & $0.070 \pm 0.011^{\mathrm{e}}$ & $0.699 \pm 0.009^{\mathrm{d}}$ \\
Aqueous & $3.197 \pm 0.046^{\mathrm{a}}$ & $1.537 \pm 0.007^{\mathrm{b}}$ & $6.697 \pm 0.025^{\mathrm{a}}$ \\
Bound Extract & $0.377 \pm 0.007^{\mathrm{c}}$ & $0.959 \pm 0.054^{\mathrm{c}}$ & $1.348 \pm 0.134^{\mathrm{c}}$ \\
BHT & & $0.021 \pm 0.012^{\mathrm{C}}$ & \\
\hline
\end{tabular}

Values represent means \pm SD (standard deviation). Values with no letter in common in each column are not significantly different $(p<0.05)(n=3)$; Different lowercase letters denote significant differences in the same column; ns: not significant; BHT: Butylated hydroxytoluene.

\subsection{Antioxidant Activity with the $\beta$-Carotene Bleaching Method}

Unsaturated $\beta$-carotene can be damaged by linoleic acid to produce linoleate and other free radicals in a chemical process, namely, $\beta$-carotene-bleaching; antioxidants are capable of neutralizing these free radicals [16]. Antioxidant tests that used the discoloration of $\beta$-carotene are widely used, as $\beta$-carotene is extremely sensitive to intermediate oxidative free radicals [28]. All extracts of Phal. Sogo Yukidian "V3" cultivar sampled inhibited $\beta$-carotene oxidation (Figure 2a). The polar extracts, ethyl acetate, and aqueous solution exhibited superior inhibition to the non-polar extracts, hexane and chloroform, and bound phenolic extracts. The LPI values of sample extracts ranged from $33.4 \%$ to $94.2 \%$ (Figure $2 \mathrm{~b}$ ). The free linoleic acid is formed when the abstraction of a hydrogen atom from one of the dialytic methyl groups attacks the molecules of unsaturated $\beta$-carotene. When the molecules of $\beta$-carotene lose their oxidative double bond, the resulting compound will lose its orange color. The presence of antioxidant activity in various extracts can interfere with the bleaching of $\beta$-carotene levels by neutralizing the free radicals formed in the system [29]. 


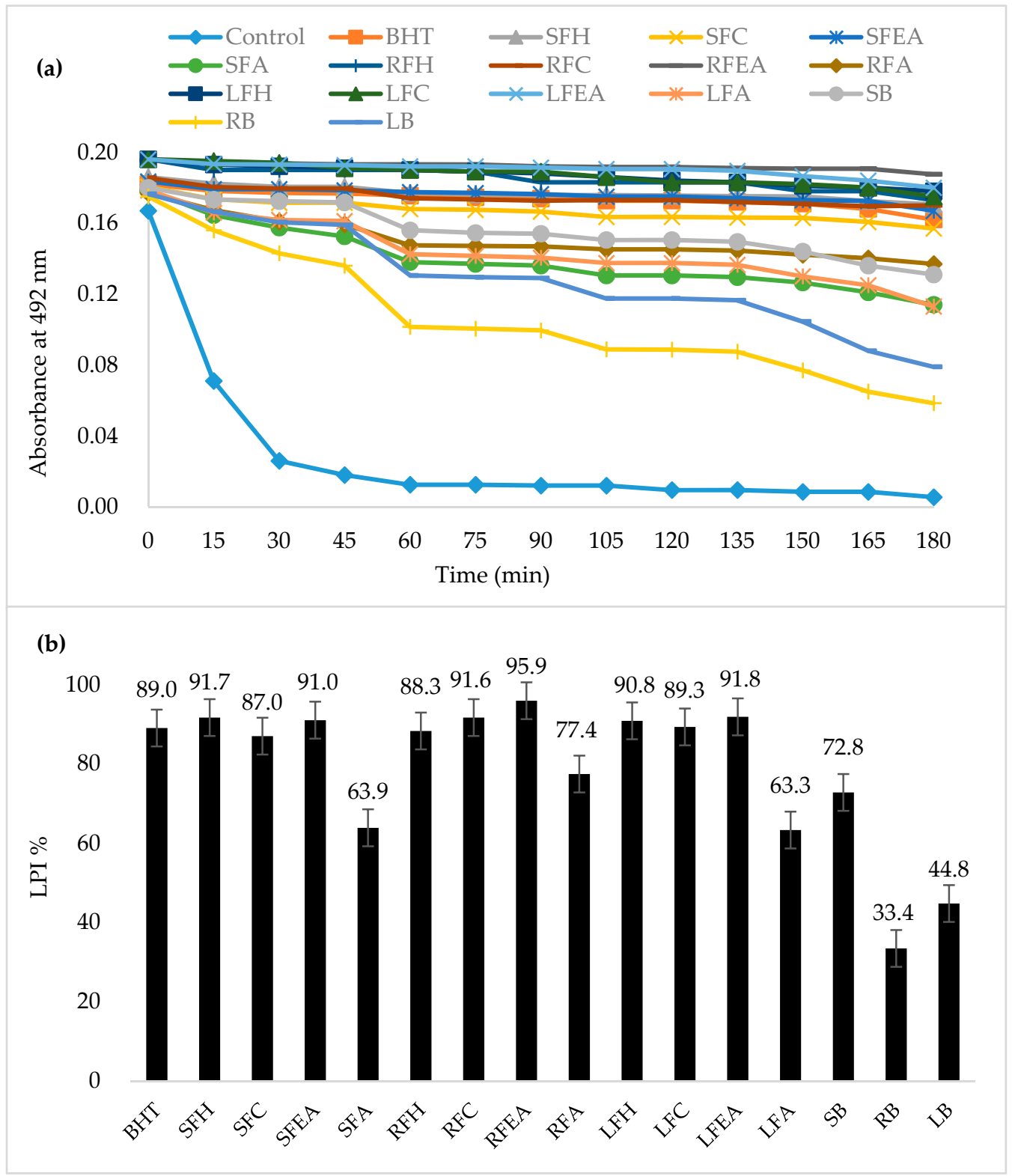

Figure 2. Antioxidant activity of Phal. Sogo Yukidian "V3" orchid sample extracts measured by $\beta$-carotene bleaching method (a) and their lipid peroxidation inhibition (\%LPI) (b) Control (MeOH); BHT: Butylated hydroxytoluene. SFH: Stem free hexane, SFC: Stem free chloroform, SFEA: Stem free ethyl acetate, SFA: Stem free aqueous, RFH: Root free hexane, RFC: Root free chloroform, RFEA: Root free ethyl acetate, RFA: Root free aqueous, LFH: Leaf free hexane, LFC: Leaf free chloroform, LFEA: Leaf free ethyl acetate, LFA: Leaf free aqueous, SB: Stem bound, RB: Root bound, LB: Leaf bound.

\subsection{Reducing Power}

The potential antioxidant activity of a compound is indicated by its ability to transfer electrons (reducing power). Sample extracts with high antioxidant activity also have a high reducing power [10]. Figure 3 shows the reducing power of hexane, chloroform, ethyl acetate, aqueous, and bound extracts prepared from the stems, roots, and leaves of Phal. Sogo Yukidian "V3". In this assay, the yellow color of the test solution varied between green and blue, depending on the reduction capacity of each compound. The presence of substances arising from the degradation of antioxidants contributed to the reduction of $\mathrm{Fe}^{3+}$ to $\mathrm{Fe}^{2+}$ [30]. 


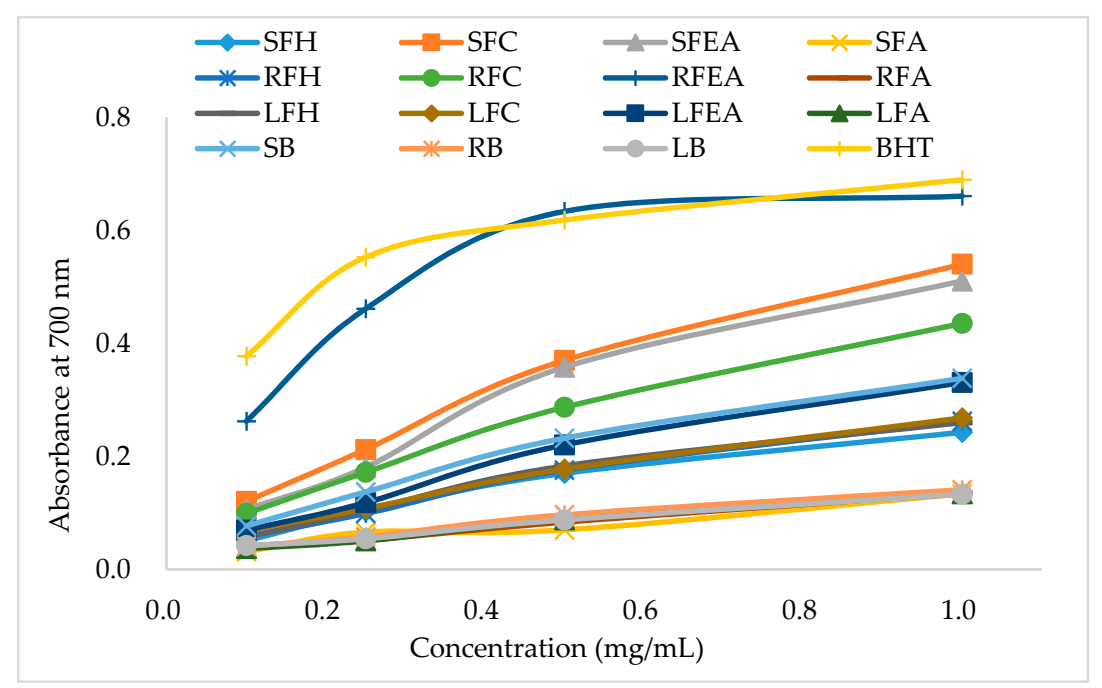

Figure 3. Reducing power of Phal. Sogo Yukidian "V3" orchid sample extracts. BHT: Butylated hydroxytoluene. SFH: Stem free hexane, SFC: Stem free chloroform, SFEA: Stem free ethyl acetate, SFA: Stem free aqueous, RFH: Root free hexane, RFC: Root free chloroform, RFEA: Root free ethyl acetate, RFA: Root free aqueous, LFH: Leaf free hexane, LFC: Leaf free chloroform, LFEA: Leaf free ethyl acetate, LFA: Leaf free aqueous, SB: Stem bound, RB: Root bound, LB: Leaf bound.

The reducing power of all sample extracts was proportionate to the concentrations applied. The ethyl acetate extracts exhibited a higher ability to reduce $\mathrm{Fe}^{3+}$ to $\mathrm{Fe}^{2+}$ than those of the chloroform, hexane, aqueous, and bound extracts. For the stem extracts, the reducing power $\mathrm{IC}_{50}$ values ranged from 0.871 to $4.495 \mathrm{mg} / \mathrm{mL}$, the $\mathrm{IC}_{50}$ values ranged from 1.544 to $4.553 \mathrm{mg} / \mathrm{mL}$ for the leaf extracts, and 0.450 to $4.354 \mathrm{mg} / \mathrm{mL}$ for the root extracts (Table 3).

Table 3. Reducing power of Phal. Sogo Yukidian "V3" orchid in terms of $\mathrm{IC}_{50}$ values.

\begin{tabular}{cccc}
\hline \multirow{2}{*}{ Samples } & \multicolumn{3}{c}{ IC $_{\mathbf{5 0}}(\mathbf{m g} / \mathbf{m L})$} \\
\cline { 2 - 4 } & Stems & Roots & Leaves \\
\hline Hexane & $2.191 \pm 0.025^{\mathrm{b}}$ & $2.018 \pm 0.013^{\mathrm{b}}$ & $2.029 \pm 0.037^{\mathrm{b}}$ \\
Chloroform & $0.871 \pm 0.012^{\mathrm{d}}$ & $1.143 \pm 0.019^{\mathrm{c}}$ & $2.020 \pm 0.022^{\mathrm{b}}$ \\
Ethyl acetate & $0.929 \pm 0.007^{\mathrm{d}}$ & $0.450 \pm 0.005^{\mathrm{d}}$ & $1.544 \pm 0.067^{\mathrm{c}}$ \\
Aqueous & $4.495 \pm 0.051^{\mathrm{a}}$ & $4.354 \pm 0.087^{\mathrm{a}}$ & $4.312 \pm 0.112^{\mathrm{a}}$ \\
Bound extract & $1.523 \pm 0.068^{\mathrm{c}}$ & $4.167 \pm 0.105^{\mathrm{a}}$ & $4.553 \pm 0.099^{\mathrm{a}}$ \\
BHT & & $0.262 \pm 0.005$ & \\
\hline
\end{tabular}

The values presented represent means \pm SD (standard deviation) $(p<0.05)$. Values with no letter in common in each column are not significantly different $(n=3)$; Different lowercase letters denote significant differences in the same column; BHT: Butylated hydroxytoluene.

\subsection{HPLC Quantification}

The hexane, chloroform, ethyl acetate, aqueous, and bound extracts prepared from the stems, roots, and leaves of Phal. Sogo Yukidian "V3" cultivar contained high amounts of phenolic compounds and showed strong antioxidant activity. These extracts were used to identify and quantify the individual phenolic acids.

Using HPLC, five compounds including caffeic acid, syringic acid, vanillin, ellagic acid, and cinnamic acid were detected in varying quantities (Table 4). Among these phenolics, caffeic and ellagic acids were most prevalent in leaves. Caffeic acid ( $574.75 \mu \mathrm{g} / \mathrm{g}$ DW), syringic acid (16.98 $\mu \mathrm{g} / \mathrm{g} \mathrm{DW})$, and cinnamic acid $(15.43 \mu \mathrm{g} / \mathrm{g}$ DW) were found only in the hexane extracts of stems, ethyl acetate extracts of roots, and chloroform extracts of stems. Furthermore, vanillin was detected in the ethyl acetate 
extracts of roots $(11.06 \mu \mathrm{g} / \mathrm{g} \mathrm{DW})$ and in aqueous extracts of leaves $(51.27 \mu \mathrm{g} / \mathrm{g} D W)$. The highest concentration of ellagic acid $(143.90 \mu \mathrm{g} / \mathrm{g} \mathrm{DW})$ was found in ethyl acetate extracts of stems, followed by chloroform extracts of stems $(134.02 \mu \mathrm{g} / \mathrm{g}$ DW). Several sources indicate that phenolic acids such as ferulic, sinapic, $p$-coumaric, and ellagic acids are strong antioxidants [31-33]. Ellagic acid was reported to obtain anti-inflammatory, anti-proliferating, anti-angiogenesis, anti-cancer, anti-fungal, anti-cancer, and anti-depressant effects [34].

Table 4. Phenolic acids in Phal. Sogo Yukidian "V3" cultivar.

\begin{tabular}{cccccc}
\hline \multirow{2}{*}{ Samples } & \multicolumn{5}{c}{ Phenolic Contents $(\mu \mathrm{g} / \mathrm{g}$ DW) } \\
\cline { 2 - 6 } & Caffeic Acid & Syringic Acid & Vanillin & Ellagic Acid & Cinnamic Acid \\
\hline SFH & $574.75 \pm 3.87$ & - & - & $50.15 \pm 5.30^{\mathrm{b}}$ & - \\
SFC & - & - & - & $134.02 \pm 0.14^{\mathrm{a}}$ & $15.43 \pm 0.10$ \\
SFEA & - & - & - & $143.90 \pm 0.14^{\mathrm{a}}$ & - \\
SFA & - & - & - & - & - \\
RFH & - & - & - & - & - \\
RFC & - & - & - & $7.05 \pm 1.41^{\mathrm{d}}$ & - \\
RFEA & - & $16.98 \pm 10.35$ & $11.06 \pm 1.22$ & $21.09 \pm 21.09^{\mathrm{c}}$ & - \\
RFA & - & - & - & $11.00 \pm 0.02^{\mathrm{cd}}$ & - \\
LFH & - & - & - & - & - \\
LFC & - & - & - & $71.08 \pm 0.09^{\mathrm{b}}$ & - \\
LFEA & - & - & - & - & - \\
LFA & - & - & $51.27 \pm 0.09$ & - & - \\
SB & - & - & - & - & - \\
RB & - & - & - & - & - \\
LB & - & - & $\mathrm{ns}$ &
\end{tabular}

Values presented represent the mean \pm SD. Values with no letter in common in each column are not significantly different $(p<0.05)(n=3)$. Different lowercase letters denote significant differences in the same column; ns: not significant. SFH: Stem free hexane, SFC: Stem free chloroform, SFEA: Stem free ethyl acetate, SFA: Stem free aqueous, RFH: Root free hexane, RFC: Root free chloroform, RFEA: Root free ethyl acetate, RFA: Root free aqueous, LFH: Leaf free hexane, LFC: Leaf free chloroform, LFEA: Leaf free ethyl acetate, LFA: Leaf free aqueous, SB: Stem bound, RB: Root bound, LB: Leaf bound.

\section{Discussion}

Plants are known to provide substances and chemicals effective in the treatment and remedy of various diseases [35-38]. Orchids constitute an order of royalty in the world of ornamental plants, are important for large horticulture, and play an important role in balancing forest ecosystems. Orchids are economically important as they are used not only for decorative purposes, but also for the treatment of certain diseases in traditional medicines [35]. Tubers and pseudobulbs of several orchids like Orchis latifolia, Orchis mascula, Cymbidium aloifolium, Zeuxine strateumatica, and some species of Dendrobium, Eulophia, and Habenaria, can treat a host of diseases [39]. The roots of Vanda tessellate can be used for manufacturing poison antidotes as well as for treating rheumatic and abdominal pain [40]. Dendrobium fimbriatum has been used as a treatment for liver upset and nervous debility, while Dendrobium teretifolium has been used for headache and pain relief. Hawkes [41] and Withner et al. [42] reported that Oberonia, Eria, Bulbophyllum, Eulophia, Geodorum, Grammatophylum, and Hetaeria could be used as a traditional medicine against various diseases.

There are an impressive number of modern medicines that have been isolated from natural sources [43]. In this study, the method of sequential extraction with different solvents (hexane, chloroform, ethyl acetate, and water) revealed a rich presence of flavonoids and phenols. Although, among 15 individual phenolic acids used as standards, there were only five constituents detected by HPLC from the waste materials of the orchid (Table 4). The existence of other individual flavonoids and phenols in low concentrations, and antioxidants other than flavonoids and phenolics, should be investigated by using analytical instruments with higher sensitivity of detection such as gas 
chromatography-mass spectrometry (GC-MS). Extracts with phenolic substance-medicated antioxidant activity were shown in conjunction with the development of reducing power [44]. As such, the ethyl acetate extract may contain much higher amounts of electron donors for reducing, and they can react with free radicals to convert them into more stable products, terminating the radical chain reaction.

The findings of this study suggest that waste material from orchids resulting from the production process for commercial flowers may be exploited as a natural source of antioxidants. In 2009, Thailand exported $\$ 80$ million US worth of orchids, of which the Phal. cultivar comprised $23 \%$ of that total [45]. In 2012, Taiwan was the foremost exporter of the Phal. plant (69\%) which, of a total of $\$ 164.70$ million US, the major cultivar was the Phal. Sogo Yukidian "V3" [4]. Rich antioxidants were found in the roots, with well-known phenolic compounds-caffeic acid at $574.75 \mu \mathrm{g} / \mathrm{g} \mathrm{DW}$, and ellagic acid at $328.07 \mu \mathrm{g} / \mathrm{g}$ DW—in the stems. In this study, extract solvents of increasing polarity were used to examine their capacity for extracting antioxidants. It was found that ethyl acetate extracts of the roots provided maximum antioxidant yield. In general, polar solvent extracts showed greater antioxidant yield than others that were studied. One explanation is that highly polar solvents often accumulate free substances with a hydroxyl moiety, such as phenols and flavonoids [46-48]. This suggests that the root of the orchid was rich in compounds with the hydroxyl moiety, although only five free individual phenolic acids were detected by HPLC. Further analysis should be concentrated on the roots of the Phal. plant to exploit its potent antioxidant capacity.

Results of this study may be worthwhile to the principal locations of orchid production such as Taiwan, Thailand, and the Netherlands, where orchids play an active role in flower production, but waste disposal causes environmental problems and are costly to treat $[49,50]$.

\section{Conclusions}

The results of this study verified that ethyl acetate extracts from Phalaenopsis Sogo Yukidian "V3" plant parts have potent antioxidant activity and may be utilized as an efficient and safe antioxidant source. Further trials examining other medicinal and pharmaceutical properties, as well as application of further analytical instruments with higher sensitivity to determine potent constituents in the waste of the Phalaenopsis should be conducted.

Acknowledgments: The authors thank Kurousu Orchid Company, Saitama Prefecture, Japan for supply plant materials (Phalaenopsis Sogo Yukidian "V3).

Author Contributions: Truong Ngoc Minh conceived the idea, designed the experiments and wrote the manuscript. Do Tan Khang, Pham Thi Thu Ha, Phung Thi Tuyen, and Xinyan Fan contributed to review the article after comments. Nguyen Van Quan, Truong Mai Van, Nguyen Thanh Quan, and Yusuf Andriana performed the experiences in antioxidant assay. Tran Dang Xuan and Tran Dang Khanh revised and approved the final submission of the manuscript.

Conflicts of Interest: The authors declare no conflict of interest.

\section{References}

1. Johnsona, M.K.; Alexandera, K.E.; Lindquistb, N.; Loo, G. A phenolic antioxidant from the freshwater orchid, Habenaria repens. Comp. Biochem. Physiol. Part C Pharmacol. Toxicol. Endocrinol. 1999, 122, 211-214. [CrossRef]

2. Minh, T.N.; Khang, D.T.; Tuyen, P.T.; Minh, L.T.; Anh, L.H.; Quan, N.V.; Ha, P.T.T.; Quan, N.T.; Toan, N.P.; Elzaawely, A.A.; et al. Phenolic compounds and antioxidant activity of Phalaenopsis orchid hybrids. Antioxidants 2016, 5, 31. [CrossRef] [PubMed]

3. Liu, Y.C.; Lin, B.Y.; Lin, J.Y.; Wub, W.L.; Chang, C.C. Evaluation of chloroplast DNA markers for intraspecific identification of Phalaenopsis equestris cultivars. Sci. Hortic. 2016, 203, 86-94. [CrossRef]

4. Chien, K.W.; Agrawal, D.C.; Tsay, H.S.; Chang, C.A. Elimination of mixed 'Odontoglossum ringspot' and 'Cymbidium mosaic' viruses from Phalaenopsis hybrid "V3" through shoot-tip culture and protocorm-like body selection. Crop Prot. 2015, 67, 1-6. [CrossRef]

5. Zheng, Y.X.; Shen, B.N.; Chen, C.C.; Jan, F.J. Odontoglossum ringspot virus causing flower crinkle in Phalaenopsis hybrids. Eur. J. Plant Pathol. 2010, 128, 1-5. [CrossRef] 
6. Chen, W.H.; Chen, H.H. Orchid Biotechnology II; World Scientific: Singapore, 2011.

7. Srivirojana, N.; Theptepa, T.; Punpuing, S.; Guest, P.; Tun, K.; Chankham, O.; Suvansrual, A. Population pressure, utilization of chemicals in agriculture, health outcomes and solid waste management. In Proceedings of the International Conference on Integrated Solid Waste Management in Southeast Asian Cities, Siem Reap, Cambodia, 5-7 July 2005.

8. Fan, M.-F. Environmental justice and nuclear waste conflicts in Taiwan. Environ. Polit. 2006, 15, 417-434. [CrossRef]

9. Su, D.; Zhang, R.; Hou, F.; Zhang, M.; Guo, J.; Huang, F.; Deng, Y.; Wei, Z. Comparison of the free and bound phenolic profiles and cellular antioxidant activities of litchi pulp extracts from different solvents. BMC Complement. Altern. Med. 2014, 14, 9.

10. Elzaawely, A.A.; Xuan, T.D.; Tawata, S. Antioxidant and antibacterial activities of Rumex japonicus HOUTT Aerial parts. Biol. Pharm. Bull. 2005, 28, 2225-2230. [CrossRef] [PubMed]

11. Tuyen, P.T.; Khang, D.T.; Minh, L.T.; Minh, T.N.; Ha, P.T.T.; Elzaawely, A.A.; Xuan, T.D. Phenolic compounds and antioxidant activity of Castanopsis phuthoensis and Castanopsis grandicicatricata. Int. Lett. Nat. Sci. 2016, 55, 77-87. [CrossRef]

12. Quan, N.V.; Khang, D.T.; Dep, L.T.; Minh, T.N.; Nobukazu, N.; Xuan, T.D. The potential use of a food-dyeing plant Peristrophe bivalvis (L.) Merr. in Northern Vietnam. Int. J. Pharm. Phytopharmacol. Eth. 2016, 4, 14-26. [CrossRef]

13. Djeridane, A.; Yousfi, M.; Nadjemi, B.; Boutassouna, D.; Stocker, P.; Vidal, N. Antioxidant activity of some Algerian medicinal plants extracts containing phenolic compounds. Food Chem. 2006, 97, 654-660. [CrossRef]

14. Elzaawely, A.A.; Tawata, S. Antioxidant activity of phenolic rich fraction obtained from Convolvulus arvensis L. leaves grown in Egypt. J. Crop. Sci. 2012, 4, 32-40. [CrossRef]

15. Siddhuraju, P.; Becker, K. Studies on antioxidant activities of mucuna seed (Mucuna pruriens var utilis) extract and various non-protein amino/imino acids through in vitro models. J. Sci. Food Agric. 2003, 83, 1517-1524. [CrossRef]

16. Soares, A.A.; Marques de Souza, C.G.; Daniel, F.M.; Ferrari, G.P.; Gomes da Costa, S.M.; Peralta, R.M. Antioxidant activity and total phenolic content of Agaricus brasiliensis (Agaricus blazei Murril) in two stages of maturity. Food Chem. 2009, 112, 775-781. [CrossRef]

17. Tuyen, P.T.; Khang, D.T.; Ha, P.T.T.; Hai, T.N.; Elzaawely, A.A.; Xuan, T.D. Antioxidant capacity and phenolic contents of three Quercus species. Int. Lett. Nat. Sci. 2016, 54, 85-99. [CrossRef]

18. Xuan, T.D.; Tsuzuki, E.; Terao, H.; Matsuo, M.; Khanh, T.D. Correlation between growth inhibitory exhibition and suspected allelochemicals (phenolic compounds) in the extract of alfalfa (Medicago sativa L.). Plant. Prod. Sci. 2003, 6, 165-171. [CrossRef]

19. Atanassova, M.; Georgieva, S.; Ivancheva, K. Total phenolic and total flavonoid contents, antioxidant capacity and biological contaminants in medicinal herbs. J. Univ. Chem. Technol. Metall. 2011, 46, 81-88.

20. Havsteen, B. Flavonoids, a class of natural products of high pharmacological potency. Bio. Phar. 1983, 32, 1141-1148. [CrossRef]

21. Deepa, V.S.; Kumar, P.S.; Latha, S.; Selvamani, P.; Srinivasan, S. Antioxidant studies on the ethanolic extract of Commiphora spp. Afr. J. Biotechnol. 2009, 8, 1630-1636.

22. Shahidi, F.; Janitha, P.K.; Wanasundara, P.D. Phenolic antioxidants. Crit. Rev. Food Sci. Nutr. 1992, 32, 67-103. [CrossRef] [PubMed]

23. Sofowora, A. Recent trends in research into African medicinal plants. J. Ethnopharmacol. 1993, 38, $209-214$. [CrossRef]

24. Das, N.P.; Pereira, T.A. Effects of flavonoids on thermal autoxidation of palm oil: Structure-activity relationships. J. Am. Oil Chem. Soc. 1990, 67, 255-258. [CrossRef]

25. Cook, N.C.; Samman, S. Flavonoids-Chemistry, metabolism, cardioprotective effects, and dietary sources. J. Nutr. Biochem. 1996, 7, 66-76. [CrossRef]

26. Blois, M.S. Antioxidant determinations by the use of a stable free radical. Nature 1985, 181, 1199-1200. [CrossRef]

27. Quan, N.T.; Anh, L.A.; Khang, D.T.; Tuyen, P.T.; Toan, N.P.; Minh, T.N.; Minh, L.T.; Bach, D.T.; Ha, P.T.T.; Elzaawely, A.A.; et al. Involvement of secondary metabolites in response to drought stress of rice (Oryza sativa L.). Agriculture 2016, 6, 23. [CrossRef] 
28. Kumazawa, S.; Taniguchi, M.; Suzuki, Y.; Shimura, M.; Kwon, M.S.; Nakayama, T. Antioxidant activity of polyphenols in carob pods. J. Agric. Food Chem. 2002, 50, 373-377. [CrossRef] [PubMed]

29. Jayaprakasha, G.K.; Singh, R.P.; Sakariah, K.K. Antioxidant activity of grape seed (Vitis vinifera) extracts on peroxidation models in vitro. Food Chem. 2011, 73, 285-290. [CrossRef]

30. Ferreira, I.C.F.R.; Baptista, P.; Vilas-Boas, M.; Barros, L. Free-radical scavenging capacity and reducing power of wild edible mushrooms from northeast Portugal: Individual cap and stipe activity. Food Chem. 2007, 100, 1511-1516. [CrossRef]

31. Kikuzaki, H.; Hisamoto, M.; Hirose, K.; Akiyama, K.; Taniguchi, H. Antioxidant properties of ferulic acid and its related compounds. J. Agric. Food Chem. 2002, 50, 2161-2168. [CrossRef] [PubMed]

32. Han, D.H.; Lee, M.J.; Kim, J.H. Antioxidant and apoptosis-inducing activities of ellagic acid. Anticancer Res. 2006, 26, 3601-3606. [PubMed]

33. Siger, A.; Czubinski, J.; Dwiecki, K.; Kachlicki, P.; Nogala-Kalucka, M. Identification and antioxidant activity of sinapic acid derivatives in Brassica napus L. seed meal extracts. Eur. J. Lipid Sci. Technol. 2013, 115, 1130-1138.

34. Khang, D.T.; Dung, T.N.; Elzaawely, A.A.; Xuan, T.D. Phenolic profiles and antioxidant activity of germinated legumes. Foods 2016, 5, 27. [CrossRef] [PubMed]

35. Mazumder, P.B.; Sharma, G.D.; Choudhury, M.D.; Nath, D.; Talukdar, A.D.; Mazumder, B. In Vitro Propagation and Phytochemical Screening of Papilionanthe teres (Roxb.) Schltr. Assam Univ. J. Sci. Technol. 2010, 5, 37-42.

36. Maridassa, M.; Hussainb, M.I.Z.; Rajuc, G. Phytochemical survey of orchids in the Tirunelveli Hills of South India. Ethnobot. Leafl. 2008, 12, 705-712.

37. Nagananda, G.S.; Rajath, S.; Shankar, P.A.; Rajani, M.L. Phytochemical evaluation and in vitro free radical scavenging activity of successive whole plant extract of orchid Cottonia Peduncularis. Res. Art. Biol. Sci. 2013, 3,91 .

38. Nagananda, G.S.; Satishchandra, N.; Rajath, S. Phytochemical evaluation and in vitro free radical scavenging activity of cold and hot successive pseudobulb extracts of medicinally important orchid Flickingeria nodosa (Dalz.) Seidenf. J. Med. Sci. 2013, 13, 401-409. [CrossRef]

39. Puri, H.S. Salep-the drug from orchids. Am. Orchid Soc. Bull. 1970, $39,723$.

40. Chowdhury, M.A.; Rahman, M.M.; Chowdhury, M.R.H.; Uddin, M.J.; Sayeed, M.A.; Hossain, M.A. Antinociceptive and cytotoxic activities of an epiphytic medicinal orchid: Vanda tessellata Roxb. BMC Complement. Altern. Med. 2014, 14, 464. [CrossRef] [PubMed]

41. Hawkes, A.D. Orchid Tea. Orchid Digest. 1944, 8, 146-147.

42. Withner, C.L.; Nelson, P.K.; Wejksnora, P.J. The Anatomy of Orchids; Wiley-Interscience: New York, NY, USA, 1974.

43. Gordon, M.C.; David, J.N. Natural product drug discovery in the next millennium. Pharm. Biol. 2011, 13, 8-17.

44. Pulido, R.; Bravo, L.; Saura-Calixto, F. Antioxidant activity of dietary polyphenols as determined by a modified ferric reducing/antioxidant power assay. J. Agric. Food Chem. 2000, 48, 3396-3402. [CrossRef] [PubMed]

45. Lekawatana, S. Thai Orchid: Current situation. In Proceedings of the Taiwan International Orchid Symposium, Tainan, Taiwan, 5 March 2010.

46. Cara, R.W.; Qingli, W.; James, E.S. Recent advances in anthocyanin analysis and characterization. Curr. Anal. Chem. 2008, 4, 75-101.

47. Simon, B.I.; Lidianys, M.L.; Claudia, L.L.; Armida, A.G.; Daniela, F.; Jose, L.R.; David, D.H. Solvent effects on phytochemical constituent profiles and antioxidant activities, using four different extraction formulations for analysis of Bucida buceras L. and Phoradendron californicum. BMC Res. Notes 2015, 8, 396.

48. David, M.P.; Patrícia, V.; José, A.P.; Paula, B.A. Phenolics: From chemistry to biology. Molecules 2009, 14, 2202-2211. [CrossRef]

49. Thammasiri, K. Current status of orchid production in Thailand. Acta Hortic. 2015, 1078, 25-33. [CrossRef]

50. Laura, B.C.; James, B.C. Orchidaceae: Using a globalized commodity to promote conservation and sustainable economic development in southern Ecuador. J. Sustain. For. 2009, 6, 799-824.

(C) 2017 by the authors. Licensee MDPI, Basel, Switzerland. This article is an open access article distributed under the terms and conditions of the Creative Commons Attribution (CC BY) license (http:/ / creativecommons.org/licenses/by/4.0/). 